\title{
Responding to the crisis: economic stabilisation grants
}

\author{
Guy Standing'
}

This article reviews some of the mainstream policies proposed to tackle the economic crisis of 2008-09 and its aftermath, and goes on to advocate a policy of economic stabilisation grants (ESGs). It argues that ESGs, which would be paid to every citizen at a rate that could be varied according to the severity of the crisis, would be more effective in boosting aggregate demand and more efficient in terms of resource allocation. Unlike the alternatives, ESGs would also address directly two key issues deriving from the process of globalisation, namely the growth of systemic uncertainty and rising inequality.

\section{The transformation crisis}

The shock of 2008 was a double crisis. First, it was a Keynesian crisis, albeit the first on a global scale. When the financial bubble burst, and panic set in, all could see that households, corporations and governments had been over-consuming and under-saving. The resultant crisis fed into shrinking aggregate demand. Faced with the prospect of a first global depression, governments rushed into a huge fiscal and monetary stimulus. This averted a slump, but did so at the longer-term cost of generating huge budget deficits. It looked as if the crisis had been checked merely to create another in its wake.

The second crisis was less appreciated. It may be called a transformation crisis, which could not be resolved by the sort of Keynesian policies that governments had embraced with alacrity. Indeed, by generating those budget deficits they risked making matters even worse. The transformation crisis reflected the growth of economic insecurity and various forms of inequality in the globalisation era. They have generated a global 'precariat', insecure and frustrated, a new dangerous class (Standing, 2009).

There were many reasons for the widening inequality. The main one was the entry of China and India into the open global economy, which quadrupled global labour supply by making a billion newcomers available to labour at a tiny fraction of the cost in rich countries. The bargaining power of capital increased and the functional distribution of income moved steadily in favour of capital. Not only did income distribution become more unequal, but conventional measures of income also underestimated its growth; non-wage enterprise benefits and state benefits were eroded for lower-income groups, while richer members of the 'salariat' retained or gained entitlement to them. Real wages in countries such as France and the United States (US) either stagnated or declined, contributing to incipient social unrest.

Although precipitated by a financial market failure, the crisis was one of systemic uncertainty converted into a problem of deficient aggregate demand through a rising ex ante propensity to save and a falling ex ante propensity to invest. This was made

Key words: economic crisis • inequality $\bullet$ uncertainty $•$ subsidies $•$ labour markets $•$ UK

Final submission October $2010 \cdot$ Acceptance October 2010

Policy \& Politics vol 39 no I • 9-25 (20 I I) • 10.1332/0305573 I IX546389 
worse by a trend towards Fisherian deflation, a downward spiral of falling assets and goods prices linked to the rundown of debt and economic contraction. For a sustainable recovery, the solution must lie not only in boosting demand but also in reducing uncertainty by promoting economic security and stability.

Globalisation and the neoliberal agenda - the building of a global market society rejected economic security. Friedrich Hayek, the Nobel Laureate economist seen as the father of globalisation and its economic policies, scornfully dismissed economic security as a false goal in his Road to serfdom (Hayek, 1944). This was the error of the globalisation era. Society rejects the human need for security at its peril.

The institutional reforms pursued since the 1980s, under the aegis of the Washington Consensus, dismantled the protective regulations and mechanisms of social democracy, including the social security system that had hinged on labourist contributions. For all its limitations, that system had automatic stabilisers; as demand fell and unemployment rose, money was pumped out via state benefits, thereby tending to restore aggregate demand. By the 1980s, old-style social democracy was no longer progressive or sustainable. But the main consequence of the neoliberal strategy was not just more economic insecurity, sold as the necessary price for increased growth and flexibility. The character of economic insecurity also changed.

To understand the globalisation crisis and what policies are feasible and desirable, it is essential to understand the nature of current economic insecurity. Briefly, in the post-1945 'Keynesian welfare state' era, the main forms of insecurity in industrialised countries were labour-based contingency risks, involving what Beveridge (1942: 7) famously called temporary 'interruption of earning power'. For the majority in the labour market, the probability of unemployment was low and a solidaristic unemployment insurance benefit scheme worked reasonably well. This is no longer the case.

The global market society creates three distinctive features - volatility, a longterm trend towards greater functional income inequality, and systemic uncertainty associated with a higher propensity for economies to suffer from periodic shocks. The global economy has become more prone to economic crises, involving sudden downturns that spread from one country or region to others (ILO Socio-Economic Security Programme, 2004: 27). ${ }^{2}$ Moreover, as Reinhart and Rogoff (2009) have shown, downturns after banking crises are typically long and deep, touching bottom only after two years while unemployment reaches its peak almost five years after a crash. For these reasons, devising a system to provide ex post compensation for adverse outcomes of risk and uncertainty has become impossible. Any system to insure against shocks would require high premiums and entail extensive moral and immoral hazards. ${ }^{3}$

There was ample warning of the financial crisis. And there is no evidence or reason for thinking that the incidence of shocks will decline or that the growing functional income inequality will be reversed without corrective action. That is the economic context. Sooner or later governments will overcome the toxic debt situation. ${ }^{4}$ But we need to know how to overcome the systemic uncertainty and reverse the growing income inequality that characterise the transformation crisis.

A Global Transformation has been taking place, in which impediments to a global market society have been eroded, strategically and deliberately. As Polanyi (2001: 147) said of similar developments in the 19th and early 20th centuries, 
'Laissez-faire was planned'. Using his terms, the globalisation era has been one of 'disembeddedness', when the economy is largely outside the control of society. In the Polanyian framework, any attempt to create 'self-regulating markets' cannot continue without mounting social, economic and political dangers. Insecurities and inequalities multiply until a crisis occurs that demands a new system of protection, regulation and redistribution. However, whereas Polanyi was analysing the creation of national market economies - and was too teleological for comfort - today's transformation is about the painful forging of a global market economy. We have yet to adapt to that paradigm shift.

A crisis will not necessarily lead to a period of 're-embeddedness', with moderated insecurities and inequalities. The present crisis nevertheless provides the opportunity and the challenge to sculpt new policies and institutions that will re-embed the economy in society.

In thinking of new policies, five interpretative points, or premises, should be borne in mind. First, the globalisation era has not been one of deregulation. In the labour market, the sphere of economic policy with which I am most familiar, probably more new regulations have been introduced than in any comparable period of history. It was the nature of the regulations that changed. There has never been a period of deregulation.

Second, the role of the state and of government has not 'shrunk', as is commonly asserted. But it too has changed. Fiscal and social security policies, for instance, have been transformed under the impact of globalisation, from being mildly progressive and solidaristic - providing low-wage earners with social security - to being regressive and increasingly directional.

The reduction in progressivity has been rationalised by claims that more incentives were needed for investors and merit-worthy individuals, who might go abroad unless they were humoured. The reduction in the social solidarity character of welfare systems of most countries was rationalised by a desire to cut public social spending and a belief that, in a well-functioning market economy, unemployment was essentially voluntary and was due to excessive protective regulations, 'rigidities' and high reservation wages. Consequently, unemployment was seen increasingly as due to personal failings. The shift to means testing was followed by acknowledgement of poverty and unemployment 'traps', which was followed by tighter behavioural controls on those on the margins of the labour market.

Third, it would be folly if a new generation of policy makers tried to recreate the policies and institutions of a past 'golden age'. There were good reasons for dismantling the social democratic architecture, even though for a period it had been a progressive and functional set of arrangements. The welfare state, in its various guises, was suited to an industrial society and a closed economy model. We now have a 21 st-century tertiary society and increasingly open economies. Trying to opt for some sort of 'de-globalisation' would be populist and doomed.

Fourth, the national and international banking and financial markets should be regulated more effectively. This must involve international coordination, if only because liberalisation has made financial market integration a reality. A few decades ago, if one stock market declined, investors could switch to another where 'prices' were rising. By about 1980, movements on the US stock exchange were followed in the same direction by other stock exchanges about $40 \%$ of the time. Now, that 
happens in about $90 \%$ of cases. This is merely an indicator of the extent of global economic integration. It stretches credulity to imagine that it will be reversed.

Fifth, the crisis has punctured a key presumption of the globalisation model, that inequality does not matter. Not only have earned incomes become more unequal but so have sources of security; the wealthy have access to more sources of income protection than those on low incomes.As Wilkinson and Pickett (2009) have shown, it is inequality rather than wealth or income level as such that produces a high incidence of most social ills. Rising inequality leads to more anxiety, status frustration, stress and social illness for all groups, not just the poorest and most insecure. The widening of income inequality in the United Kingdom (UK) since the 1980s has been the greatest in the developed world, implying that it has been due in part to political decisions, with the result that the UK now has the third highest level of income inequality after the US and Portugal.

Part of the genius of Franklin Roosevelt is said to have been his early recognition that the biggest problem in the Depression was the basic structural flaw in the economy that had produced a severe maldistribution of wealth, coupled with excessively low incomes and wages (Badger, 2009). The current US President, Barack Obama, also appears to have recognised that the biggest flaw in the globalisation model of market capitalism has been its willing acceptance of rising income inequality. Income distribution is back on the political agenda.

The following reviews some of the mainstream policies proposed to tackle the crisis and goes on to advocate a policy of economic stabilisation grants (ESGs) that takes account of these contextual points. In all cases, it would be appropriate to apply policy 'stress tests' that, in this author's view, should not only include economic effectiveness (boosting aggregate demand) and efficiency (improving use of resources), but also whether the policy addresses the two key issues of systemic uncertainty and rising inequality.

\section{Conventional policy alternatives}

The global crisis has taken its toll on many millions of people's lives. Citizens are encouraged to scowl at a token handful of individuals - 'bankers'. Governments desperately acted to keep failed institutions alive and suspended their past reasoning in the quest to rescue them. If they were real neoliberals, they should have ruled out rescue plans. Let the market do its job! The plans that emerged implied a new depth to the notion of moral hazard.

Let us leave that to the conscience of those who claim to believe in the old model and instead consider what seem to be the mainstream responses.

\section{Quantitative easing}

The UK government and the Bank of England placed great faith in 'quantitative easing', an ungainly term for increasing the money supply. It was necessary. But it was not a policy; it was a reaction. It was introduced by policy makers whose position had imploded. That surely cannot instil confidence that the reaction was properly thought through. 
There is historical evidence to support the idea. Friedman and Schwartz (2008), in their book The great contraction, concluded that the Federal Reserve's quantitative easing after 1932, through purchasing Treasury bonds to keep yields low, was vital in dragging the US economy out of the Depression. Amusingly, Ben Bernanke, the Federal Reserve Chairman, when advocating quantitative easing, referred to the metaphor of dropping money from helicopters, drawing from a famous essay by Friedman (1969: 4-5) and promptly earning himself the nickname of 'Helicopter Ben'.

The use of conventional monetary policy to respond to the financial crisis was constrained by the fact that interest rates were already close to zero, making it impractical to lower them to boost demand. This is the essence of the Keynesian liquidity trap. The intention of quantitative easing was to expand the money supply directly to increase the availability of credit and boost investment, partly by raising confidence. But a downside of quantitative easing is that it penalises savers, giving a twist to the liquidity trap. Cutting interest rates, and feeding money to borrowers, meant that those who had saved for retirement or to supplement low earnings, had a lower income flow and had to run down their capital (savings). Since savers outnumber borrowers by about six to one, the policy was prima facie inegalitarian.

Savers had done nothing wrong, except to follow the urgings of successive governments and mainstream economists over two decades. The International Monetary Fund (IMF), World Bank and Organisation for Economic Co-operation and Development (OECD) had all eulogised 'private savings accounts' and definedcontribution private pensions. Now those who took their advice were penalised. Quantitative easing may help them in the medium term - for those who live that long - if it lifts economic activity. But a combination of zero real interest rates, and an inflationary injection of money going to others, could not make ordinary savers feel more secure.

In addition, quantitative easing was a reaction to a systemic lack of confidence, which may in fact be exacerbated by lurches in policy. As Keynes noted (1936: 172): 'A large increase in the quantity of money may cause so much uncertainty about the future that liquidity preferences due to the precautionary motive may be strengthened'. The European Economic Advisory Group declared in its 2009 report on the European economy (EEAG, 2009) that 'there is even the possibility that large interventions paradoxically exacerbate the fall in consumer and business confidence, by conveying the message that the crisis is far worse than expected'. The Economist (2009a: 74) also concluded: 'people (and banks) may cling to cash more tightly if they are spooked'. There is something 'spooky' about quantitative easing.

In a fascinating paper (Haldane, 2009), the Bank of England's newly appointed executive director for financial stability, said that banks had not understood the risks they were taking through a mixture of 'disaster myopia' (a tendency to underestimate risk), lack of awareness of 'network externalities' (spillovers from one institution to another) and 'misaligned incentives'. One feels like asking if this was the time to put faith in the financial sector to revive the economy.

In short, monetary policy may have achieved a temporary revival, but it did so in a costly, inefficient and limited way. It failed to deal with systemic uncertainty and may have exacerbated rather than attenuated inequalities. 


\section{Subsidies and industrial policy}

Proponents of selective subsidies argued that, given a general collapse of demand, firms that were 'otherwise viable' should be helped until conditions improved. Governments made liquidity and other forms of support for banks conditional on increased focus on domestic lending (Warner, 2009), extended loan guarantees and paid out billions of dollars to keep other hard-hit sectors, notably the car industry, afloat.

The various 'cash for clunkers' schemes, in France, Germany and the US, for example, succeeded in inducing people to buy new cars but, once the costly schemes ended, demand predictably plummeted. Meanwhile, bailouts of so-called 'strategic' industries (which in France included Meccano, a venerable toy manufacturer) have spawned a revival of industrial policy across the industrialised world, with the US, Japan and European countries all vying to boost manufacturing competitiveness and jobs, often in the same industries. Industrial policy amounts to identifying and giving selective subsidies to potential winners; it has been tried in many places at many times and has mostly failed after vast sums have been spent (see The Economist, 2010). This time will be no different. While manufacturing was particularly hard hit by the crisis (The Economist, 2009b), global de-industrialisation and restructuring have been taking place over several decades. Globally, there will be fewer manufacturing jobs after the recession.

Instead, the world is in danger of slipping into an era of subsidy protectionism, as governments turn to subsidies in increasingly clever guises.Apart from subsidies aimed directly at particular industries, mostly crafted to skirt World Trade Organization (WTO) rules, tax credits paid to top up wages, such as the US Earned Income Tax Credit, also subsidise labour-intensive, low-paying sectors, reducing the cost of domestic production and making it harder for imports to compete. They are thereby trade distorting, even though they have escaped WTO scrutiny for the moment.

In the present crisis, governments have turned to labour subsidies of various kinds in their attempts to bring down the unemployment count.Yet, such subsidies have five common failings. They are cumbersome and costly to administer. They encourage and reward inefficiency. They induce huge substitution effects (employers recruit people who are subsidised in place of unsubsidised workers). They have huge deadweight effects (the jobs would have been created anyway, regardless of the subsidy). And they are usually inequitable and regressive, often in concealed ways.

One popular subsidy is wage assistance for short-time working as an alternative to redundancy. As one commentator (Warner, 2009) put it:

For countries with relatively high levels of social security benefit, it makes some sense. Paying workers to do nothing but to be ready to reapply themselves when the economy picks up may seem preferable to paying them dole and having their skills lost for ever to the ranks of the long-term unemployed.

In the Netherlands, the government agreed to pay most of the wages for a short period if workers were put on a three-day or four-day week. In the UK, this was urged by union leaders such as Tony Woodley, joint general secretary of the union Unite (Woodley, 2009). 
An economist should be more sceptical. Keeping workers on the books in the unwinding Soviet Union had disastrous consequences, as it did in China in the late 1990s. Such workers are less likely to acquire new skills that might be needed in a recovery, and may become more prone to social illnesses than those obliged to come to terms with new economic realities while they still have energy and savings. Moreover, firms under pressure would be encouraged to take the easy option, putting workers on short time and taking a subsidy, when they might otherwise take different actions that would prepare them for restructuring to take advantage of an upturn. And, if a government supports one sector, it will soon be under pressure to support others as well.

Even more popular have been marginal employment subsidies, intended to encourage job creation. In June 2010, the first budget of the new UK coalition government granted start-up businesses outside the South East a 12-month exemption from National Insurance (social security) contributions on the first 10 people they hire, up to a maximum of $£, 5,000$ per employee or $\mathcal{E} 50,000$ per firm. The government estimates that some 400,000 firms could qualify. In the US, the Hiring Incentives to Restore Employment Act, signed into law in March 2010, gives tax credits to businesses that hire workers who have been unemployed for eight weeks or more. By September 2010, the US administration was claiming that firms qualifying for the credit had hired 5.6 million workers.

Many economists have argued in favour of marginal employment subsidies, the leading advocate being the Nobel Prize winner, Edmund Phelps (1997). Yet they are inefficient and contribute to protectionism via the backdoor (for a critique, see Standing, 2002: chapter 9). Evaluations of previous schemes show very high deadweight and substitution effects - over 95\% for Ireland's Employment Incentive Scheme in the 1980s, for instance (Betcherman and Islam, 2001: 319). Schemes of this sort also produce moral and immoral hazards. One is what I have called auntie effects. Suddenly, auntie is employed, at a very low wage no doubt, and an application is in the post to obtain the subsidy. In the Netherlands, a wage subsidy was introduced for firms if they had suffered a 30\% sales decline over two months. This could induce firms to make sure their sales decline passed the 30\% threshold.

Another drawback is the unfairness of subsidies given for new jobs, or to new firms. Why should a firm that expands now be given a subsidy when another has been providing jobs for many years? After all, if the subsidy works as claimed, it will lower production costs for the newer firm, thus weakening the position of the older firm. It may even jeopardise the survival prospects of the older firm, which might be the more productive. This would be neither fair nor economically sensible.

Subsidies benefit middle-income and higher-income groups disproportionately and 'leakages' are notoriously high. In other words, the boost to aggregate demand is less than implied by the sum spent on them. This is partly because the more affluent have a relatively low average and marginal propensity to consume, and partly because this group has an above-average propensity to spend on imported goods and services. So, to give a net boost to the national economy, the gross sum must be much larger.

In sum, subsidies (and industrial policy) fail all the policy stress tests. They are ineffective in raising aggregate demand and employment; they are inefficient, distorting resource allocation; they do nothing to alleviate uncertainty; and they are inegalitarian, benefiting the better off rather than the poor. 


\section{Active labour market policy}

Particularly in a recession, much hope is placed in so-called active labour market policy to put people into jobs. It is expected to boost employment, raise productivity, increase social mobility, strengthen social inclusion and reduce income inequality. And recently, its advocates have given the assurance that it will make people more 'happy'. The evidence does not bear out these claims, but that has not prevented them being repeated.

Take, for example, the article arguing in favour of active labour market policy by David Blanchflower (2009), then a member of the Bank of England's Monetary Policy Committee, who had gained credibility for having forecast a financial setback. He began by recalling the quip by Jim Heckman, the US Nobel Prizewinning economist, who said in response to a question about how much labour market training schemes had helped the unemployed, 'Zero is not a bad number'. Blanchflower then noted findings showing how subsidised employment schemes had been inefficient, even to the extent of having a negative long-term effect on the incomes of recipients. ${ }^{5}$ It is hard to understand the leap from such findings to advocating more active labour market policies. Blanchflower does so by citing research suggesting that participation in one scheme modestly raised the participants' probability of employment (Blundell et al, 2001), and a study suggesting that those who participated in the New Deal for Lone Parents (NDLP) spent less time on benefits than those who did not (Beale et al, 2008). He did not cite any other finding (for a more recent article, see Gregg et al, 2009).

These arguments are irrelevant in macroeconomic terms. They ignore the probability of large substitution and deadweight effects. The fact that those given more help than others do better than others does not mean that everybody does better. It is surely desirable to give help to those with intrinsic disadvantages. But this does not mean that the policy is advantageous as a macroeconomic device. Blanchflower gives no reason for thinking that such policies would generate more employment or economic growth (let alone happiness).

Policy proposals should correspond to the nature of the labour market and the nature of the 'class' structure, both of which are very different now from what typified the pre-globalisation era. A majority who labour and work are essentially detached from the old forms of state and enterprise benefits and the main group to have emerged is a global 'precariat', in and out of temporary, insecure or sometimes shadow-economy jobs. Partly as a result of labour liberalisation, millions have joined the precariat. Many are immigrants or the young. Those aged 15 to 24, for example, account for more than a third of people in short-term jobs in Europe, even though this age group makes up only $10 \%$ of the labour force.

Eurostat has estimated that short-term employees account for about $17 \%$ of all employees in the Euro zone. Since many people in the labour market margins are unregistered for various reasons, it would not be surprising if the actual share was well over $20 \%$. On top of that, one should add all those counted as 'self-employed' or 'independent labour contractors'.

The precariat bore the brunt of the early rounds of dis-employment. For instance, in Spain the number of officially recorded temporary workers fell by $12.7 \%$ between the last quarter of 2007 and the last quarter of 2008. In the US, the number fell 
by nearly 25\% between February 2008 and February 2009, at a time when total employment fell by just 3\%.

While the crisis induced a rapid decline in employment (even by comparison with the recession in 2001), loss of 'precariat' jobs will often not have shown up in official statistics. And, compared with the welfare state era, more of those in so-called 'permanent', or regular, employment contracts have been put on some form of short time. This makes it unlikely that raising unemployment benefits and increasing the duration of entitlement would do much as an economic stabiliser. For instance, in Germany a worker must be in full-time employment for at least a year before becoming eligible for full unemployment benefits. In most industrialised countries, only a minority of the unemployed qualifies for and receives unemployment benefits. Raising them may both increase open unemployment (because more people will register as unemployed) and cause more resentment among the precariat, which is denied them. This comment should not be interpreted as hostility to higher or longer benefits, merely a reminder of the limitations of this route.

In terms of the policy stress tests, active labour market policies have little effect on aggregate demand, are a wasteful use of resources and do not address the economic insecurity that characterises the growing precariat class. Neglected by policy makers, its members comprise the new 'dangerous class', the group most inclined to take to the streets or vote for right-wing extremists, as similar groups did in the 1930s.

\section{Public works}

In every recession there is a lobby for public works, often fuelled by misty recollections of Roosevelt's New Deal (Hutton, 2009). In this regard, one should differentiate between counter-cyclical infrastructural investment and public works, even though in practice the distinction may be blurred. Counter-cyclical infrastructural investment emphasises investment spending to provide a stimulus to demand, and hence employment. The motivation behind public works is primarily to absorb some of the unemployed, with an emphasis on labour-intensive projects, sometimes of dubious economic value.

More infrastructural investment is required, particularly in the US, where decay is palpable.The 'green' agenda is also well timed in this respect. But most infrastructure initiatives are - and should be - slow working, in that they require proper planning and careful administration. In a recession, those basics tend to be neglected. It should also be recalled that in the 1990s, Japan failed to kick-start its economy via an infrastructure-based stimulus, and that the Eisenhower public works, cited by President Obama with such enthusiasm when he signed a $\$ 787$ billion stimulus package in February 2009 in Denver, took three times as long as anticipated to roll out. It is hard to spend fast and spend well at the same time.

Public works also have large deadweight and substitution effects that, as with all subsidies, reduce the net economic effect.

One tendency displayed by the public works lobby is to slip effortlessly from saying that people 'want to work' to saying 'jobs raise the spirit', so justifying public works. Many jobs do not raise the spirit, and it ill becomes middle-class writers to presume that people's spirits are lifted by having to labour on building sites, in sewers or in dead-end jobs that they want to leave as soon as possible. If there is to 
be a public works programme, all adults should be involved in some way, as a sort of community service. Otherwise, the policy is an unedifying exercise in paternalism.

In sum, while an investment stimulus can be effective in raising demand, it can be slow to take effect. If undertaken without due preparation, or if the emphasis is on employing as many people as possible through public works, the outcome is likely to be an inefficient use of resources. Public works also do little to address systemic uncertainty or inequality.

\section{Economic stabilisation grants as shock absorbers}

To respond to this crisis point in the Global Transformation, we need new forms of regulation, social protection and redistribution appropriate for a global market system (see Standing, 2009). The primary problem is systemic uncertainty, epitomised by a rising probability of economic volatility, insecurity and widening functional income inequality. Citizens suffer stress and loss of wellbeing as a result, and consumption and investment are erratic and hypersensitive.

The circumstances demand a stabiliser - not a recipe of cognitive-behavioural therapy, proposed by the former UK Labour government to help victims deal with their misery and anxiety, but an economic stabiliser that provides ex ante basic security. The policy must act quickly while contributing to the solution of structural problems thrown up in the global market economy. I believe that the solution is quite easy. However, it looks radical, and as such will attract the reactions that Hirschman (1991) saw as the predictable responses to any new idea. ${ }^{6}$ I would just urge economists to withhold hasty judgement.

My proposal is that all citizens should receive a regular "economic stabilisation grant' (ESG), equivalent to, say, $£, 30$ a week in current circumstances, which would be credited to an electronic ESG card.

Before considering the objections that such a proposal is bound to prompt, and the advantages of moving in this direction, note the necessary conditions for success. It must be conceived as a stabilising device and as a means of responding to an inherent feature of the global economic system, its tendency to volatility. It must also be seen as a better basis for social protection in flexible labour markets than old forms of social security conceived for an industrial society, and better than the paternalistic (and coercive) policies in vogue for dealing with the unemployed. Finally, the monetary value of the ESG should be regarded as flexible, as a policy variable, just as interest rates are now.

There will be five objections. Let us consider them briefly.

First, it will be said that it is unaffordable. Roughly, a weekly payment of $\mathcal{2} 30$ would come to about $£ 75$ billion a year, or some $4 \%$ of gross domestic product (GDP). This is the same as was given to the banking community in quantitative easing, merely as a first tranche. ${ }^{7}$ Moreover, like other countries, the UK has wallowed in government subsidies. Much of that spending could have been directed to market-strengthening and security-strengthening stabilisation grants. The drawbacks of selective subsidies, most of which go directly or indirectly to relatively well-off individuals and firms, were reviewed briefly earlier. Finally, while ESGs should be universal and equal, the money going to richer members of society could be clawed back in tax, leaving the net cost well below the immediate cost. 
Another reason for believing that ESGs are affordable is that in the UK in 2009, public debt as a percentage of GDP, at $58 \%$, was significantly lower than in Italy (102\%), the US (81\%), Germany (76\%), France (72\%) and Canada (63\%) (IMF, 2009). ESGs would also seem to pass the IMF's proposed four-pillar stress test. The IMF noted that the size of automatic stabilisers is smaller in the US than in Europe because of the more limited array of state benefits - but everywhere these benefits have been shrinking. We need better automatic economic stabilisers. The IMF argued, cogently, that a country's fiscal stimulus should be larger where the normal multiplier effects are lower, and noted that the US and UK have relatively low multipliers.

A second likely objection is that ESGs would be giving something for nothing, inducing idleness and dependency. There are several retorts to this, including Tom Paine's remarkably modern argument laid out in 1795 (Paine, 2005 [1795]). Many of the conventional policies also gave something for nothing; the mega-bailouts were given largely to sectors and firms that had actually done harm. Meanwhile, ordinary people were unfairly exposed to economic uncertainty, since they could not be expected to insure against the vagaries of the economic system. Moreover, we are told that people want to work and are 'happy' when in jobs. If so, giving everybody basic security should at most induce only a tiny minority to be less hardworking than otherwise. And that minority would scarcely be a drag on the economy, since they are likely to have low potential productivity. It would cost much more to try to weed out that minority than to operate a universal rights-based scheme.

A third likely objection is that no such scheme has been introduced elsewhere, and it must therefore be too radical and unrealistic. The retorts to this should be loud and clear. We are being urged to think afresh. As Tim Geithner, US Treasury Secretary, pointed out in March 2009, 'Lots of things that did not seem realistic in the past are not just realistic but compelling' (cited in Beattie, 2009). He called for each G20 country to set a target of spending 2\% of GDP in 2009 and 2010 in fiscal stimulus. The most transparent, easily monitored, efficient and equitable way of doing this would be through ESGs.

ESGs would be less 'radical' than seems at first glance. In the US, part of the Obama stimulus package consisted of government-issued debit cards for food benefits. And Obama's 'signature tax cut' was a credit of up to $\$ 500$ for individuals and $\$ 1,000$ for couples. This was praised by the non-partisan Tax Policy Center, which noted that it could be carried out quickly. The Center criticised the credit because it was given to all groups, but it could have been clawed back from the rich through raising sales tax on luxury goods or income tax at the higher end. A more substantive limitation was that it only benefited taxpayers, omitting the many outside the taxpaying mainstream.

In 2008, the Bush administration had given a rebate to US taxpayers, but one-off tax rebates do not lead to a big jump in consumption spending. Only $30 \%$ of the rebate was spent on consumption (The Economist, 2008). The propensity to consume might increase subsequently, once fewer people wished to use the money for building savings or running down debt. But the need is to make the payment modest and continuing, rather than a one-off 'gift'. ${ }^{8}$ People react more quickly and spend more if they perceive that a boost to income is 'permanent'. 
More generally, the ESG would merely continue with the long-established notion of an economic stabiliser, now that the traditional instruments have ceased to be effective.

A fourth objection might be that universal stabilisation grants would be inflationary. However, this was not a major concern in the aftermath of the crisis, since the fear confronting policy makers was deflation. For the longer term, the value of ESGs could be varied according to the state of demand and the economic pressures, just as interest rates are adjusted to respond to the state of the economy. And what we are talking about is a reallocation of public spending, cutting out selective subsidies.

A fifth objection is that ESGs would be distorted for political ends. Any monetary or fiscal policy can be distorted, and all are used for political ends, which is why monetary and fiscal policies are typically loosened in the run-up to general elections. However, the answer in this case would be to set up an independent Economic Stabilisation Policy Committee, analogous to the Bank of England's Monetary Policy Committee. Just as the Monetary Policy Committee meets regularly to decide on changes in interest rates and quantitative easing, so the Economic Stabilisation Policy Committee could sit regularly to decide whether the ESG rate should be modified up or down.

What about the advantages of an ESG scheme?

First, it would be transparent and relatively easy to implement. Most if not all alternatives have large leakages, high administrative costs and would take a long time to implement. Second, ESGs would boost aggregate demand more efficiently and equitably than the more orthodox route of selective industrial or employment subsidies. They would go primarily to people who have a high average and marginal propensity to consume and to devote more of their spending to local goods and services.

For the same reasons, unemployment benefits have been touted as a sensible form of stabilisation spending compared with the alternatives. Raising them would have positive effects, and in the US the reforms to unemployment benefit have had the triple benefit of helping the unemployed to survive, to pay for healthcare and to hold on to their dwellings. ${ }^{10}$ However, as argued earlier, advocates should be realistic about their limited macroeconomic potential and their distributional implications in flexible open labour markets.

Third, ESGs would begin to redress what should be regarded as the biggest failing of the neoliberal model of globalisation, namely income inequality. The introduction of ESGs would address the most worrying aspect of that inequality, the lack of economic security among lower-income groups, many of whom are plunged into a cycle of impoverishment following the slightest shock or even changes in interest rates. ${ }^{11}$

The labour force of Europe is more stratified than used to be the case. Now that we have entered a global recession, barriers to social mobility may become a greater source of discontent. Perhaps the popular anger directed at 'fat cats' will lead to more demand for income redistribution. A virtue of economic stabilisation grants would be that they would reduce inequality while giving governments time to devise other methods of moderating inequality compatible with a dynamic market economy. In a global system, the long-term trend is for functional income distribution to become more skewed towards capital, so that owners of capital will earn more relative to those who rely on labour income. That trend will have to be tackled at international 
level and by designing ways of sharing capital income without disrupting economic dynamism. In the meantime, ESGs would moderate inequality while enhancing economic security and helping economic revival.

Fourth, a hidden set of advantages would flow from ESGs. Having basic security is known to induce more rational decision making, so that, for instance, workers would be more inclined to invest in skill acquisition. Psychologists have shown that security induces more tolerance, altruism and 'social responsibility', helping others and welcoming strangers, precisely the traits that seem in short supply as a result of the breakdown of traditional networks of support and social solidarity, much of which is linked to the policies pursued in the neoliberal model. ${ }^{12}$ The use of universal grants to give everybody a greater sense of economic security would strengthen communities and help create confidence that would boost local investment, pride and responsible behaviour. Having basic security would also induce more people to feel less stressed and frenetic - two of the deepest malaises of the consumerism that globalisation has encouraged. We can have too much security, but as a society we are far from that situation at present.

Fifth, ESGs would offer a mechanism for long-term stability and basic economic security. They would feed liquidity into the economy while reducing uncertainty about the future. This would help boost consumer spending, partly by reducing the ex ante propensity to save.

In sum, ESGs would help to make the market economy function more effectively and equitably, would help in curbing the growing income inequality and would help stabilise an inherently unstable system.

\section{Concluding thoughts}

Ken Rogoff, the much-cited Harvard, and formerly IMF, economist, said in 2009: 'Europe faces a plain vanilla recession. It is a deep recession and it's coming with a vengeance. But it is not a paradigm destruction' (cited in Bennhold, 2009). The Financial Times journalist, Phillip Stephens (2009: 9), wrote much the same, asserting, 'Forget the guff about new paradigms'. His targets were economists who were reinventing themselves, having earlier said that the times of boom and bust were past. Unfortunately, he overstated his case. This is a transformative crisis. The world will not look or be the same afterwards.

Major crises lead to major changes. None of us can be certain what will come of this one. Some of us hope that a more just and gentler form of market economy will emerge. We must all earnestly hope that it comes sooner rather than later, rather than after a period of political tension and extremism of Right or Left. It will take time to replace the old model. The lesson of paradigm change, as Thomas Kuhn (1996 [1970]) taught us, is that a paradigm breaks down when it cannot answer the questions being raised and cannot offer answers within its own logic. But it is only displaced when a new paradigm is ready to take its place.

I believe the paradigm shift will not be back towards the old European 'social model', because in an open economy system labourist forms of social insurance raise labour costs, induce unsustainable rigidities and erode competitiveness. Economic security must be promoted outside the labour sphere. That will be part of the paradigm shift. 
One modest recommendation is that the emerging generation of economists and social policy students should urge their peers, and particularly the new political leaders, to match their rhetoric about being 'radical' by assessing genuinely radical ideas. Economics is a constantly unfolding body of thought, and those charged with implementing economic and social policy should face demands to think afresh and evaluate alternatives with open minds.

\section{Notes}

${ }^{1}$ An earlier version of this article was presented at the Social Policy Association Conference, University of Edinburgh, 30 June 2009.

${ }^{2}$ Advocates of financial liberalisation claimed that it would produce more economic stability. As evidence accumulated showing this was not so, they, notably the International Monetary Fund (IMF), argued that short-term instability was the price for longer-term gain. This rationalisation looks odd now, and should make one wonder why so many politicians and economists think that the IMF should have an enlarged role.

${ }^{3}$ Moral hazards arise when a social protection scheme promotes unproductive behaviour. For instance, means-tested benefits favoured by the United Kingdom (UK) and other governments create poverty traps and unemployment traps, whereby taking paid work can result in a cut in income. Immoral hazards arise from the fact that, often for the same reason, it pays to be dishonest.

${ }^{4}$ Soros (2009: 10) pointed out that, in 1929, toxic debt was about $160 \%$ of gross domestic product (GDP) and it took three years to clear. In 2008, the ratio was 365\% "without taking account of the pervasive use of derivatives'.

${ }^{5}$ The original research was: Dolton et al (1994), showing that participation in an active scheme had lowered the probability of subsequent employment, and Green et al (1996), showing that being in a scheme had a negative effect on subsequent income.

${ }^{6}$ Hirschman identifies three core types of argument - perversity, futility and jeopardy - used to oppose reform: the reform will have the opposite effect to that intended; it will have no effect; or it will threaten the loss of something else.

${ }^{7}$ The IMF calculated that by early 2009 the UK had spent a fifth of its GDP on bailing out the banking system, much more than any other country; the second was Norway, which had spent $13.8 \%$; the US had spent $6.8 \%$.

${ }^{8}$ Len Burman, head of the Tax Policy Center, said of the Obama measure: 'A higher share of the tax credit is likelier to be spent than last year's rebate because it is paid out in increments rather than in one lump sum' (cited in Luce and Guha, 2009).

${ }^{9}$ This is one reason for arguing in favour of small continuing grants rather than lumpsum 'capital' transfers, since the latter involve 'weakness-of-will' effects rather than longer-term rational behaviour (see Standing, 2006). 
10 Stiglitz (2009: 9) (among others) has argued that, compared with tax cuts, 'increased unemployment benefits have the largest multiplier effects - cash-strapped families spend every cent given - and meet vital social needs'. He ignored the moral hazards of giving special assistance to people because they are in a particular condition and the fact that only about a third of unemployed Americans receive unemployment benefits.

${ }^{11}$ Consider the case of an older couple who have put away savings to earn interest to pay for their nursing home care. They did as advised by economists and governments. Now they cannot increase their savings to compensate for the very low interest rates, and will have to run them down. They must just hope that the cavalry, in the form of economic revival, arrives in time.

${ }^{12}$ For instance, the shift to means testing and 'targeting' of social assistance, advocated in the neoliberal model, has been linked to the spread of xenophobia and anti-migrant sentiment (Dench et al, 2006).

\section{References}

Badger, A.F. (2009) FDR: The first hundred days, New York, NY: Hill and Wang.

Beale, I., Bloss, C. and Thomas, A. (2008) The longer-term impact of the New Deal for Young People, Working Paper No 23, London: Department for Work and Pensions. Beattie, A. (2009) 'US urges tripling of IMF firepower', Financial Times, 12 March. Bennhold, K. (2009) 'Is Europe's welfare system a model for the 21st century?', International Herald Tribune, 27 January.

Betcherman, G. and Islam, R. (2001) East Asian labor markets and the economic crisis: Impacts, responses and lessons, Washington, DC: World Bank.

Beveridge, W. (1942) Social insurance and allied services, London: HMSO.

Blanchflower, D. (2009) What should be done about rising unemployment in the UK?, Open lecture, University of Sterling, 25 February, www.bankofengland.co.uk/ publications/speeches/2009/speech379.pdf

Blundell, R., Dias, M.C., Meghir, C. and Van Reenen, J. (2001) Evaluating the employment impact of a mandatory job search assistance program, Working Paper 01/20, London: Institute for Fiscal Studies.

Dench, G., Gavron, K. and Young, M. (2006) The new East End, London: Profile Books.

Dolton, P., Makepeace, G. and Treble, J. (1994) 'The Youth Training Scheme and the school-to-work transition', Oxford Economic Papers, 46: 629-57.

EEAG (European Economic Advisory Group) (2009) The EEAG report on the European economy, Munich: Ifo Institute for Economic Research.

Friedman, M. (1969) 'The optimum quantity of money', in M. Friedman, The optimum quantity of money and other essays, Chicago, IL: Adline Publishing, 1-50.

Friedman, M. and Schwartz,A.J. (2008) The great contraction, 1929-1933, Princeton, NJ: Princeton University Press.

Green, F., Hoskings, M. and Montgomery, S. (1996) 'The effects of company training, further education and the Youth Training Scheme on the earnings of young employees', Oxford Bulletin of Economics and Statistics, 58: 469-88. 
Gregg, P., Harkness, S. and Smith, S. (2009) 'Welfare reform and lone parents in the UK',Economic Journal, 119: F38-F65.

Haldane, A.G. (2009) Why banks failed the stress test, Speech given at the MarcusEvans Conference on Stress-Testing, London, 9-10 February.

Hayek, F. (1944) The road to serfdom, Chicago, IL: University of Chicago Press.

Hirschman, A. (1991) The rhetoric of reaction: Perversity, futility, jeopardy, Cambridge, MA: Harvard University Press.

Hutton, W. (2009) 'We can replicate the beauty that came from the Depression', The Observer, 8 February.

ILO (International Labour Office) Socio-Economic Security Programme (2004) Economic security for a better world, Geneva: ILO.

IMF (International Monetary Fund) (2009) The size of the fiscal expansion: An analysis for the largest countries, Washington, DC: IMF, www.imf.org

Keynes, J.K. (1936) The general theory of employment, interest and money, vol VII of The collected writings of John Maynard Keynes (1973), London: Macmillan.

Kuhn,T. (1996 [1970]) The structure of scientific revolutions (3rd edn), Chicago: Chicago University Press.

Luce, E. and Guha, K. (2009) 'White House injects range of spending to boost ailing patients', Financial Times, 4 February.

Paine, T. (2005 [1795]) 'Agrarian justice', in Common sense and other writings, New York, NY: Barnes \& Noble, 321-45.

Phelps, E. (1997) Rewarding work: How to restore participation and self-support to free enterprise, Cambridge, MA: Harvard University Press.

Polanyi, K. (2001) The Great Transformation: The political and economic origins of our time, Boston, MA: Beacon Press.

Reinhart, C. and Rogoff, K. (2009) The aftermath of financial crises, NBER Working Paper No 14656, Washington, DC: National Bureau of Economic Research.

Soros, G. (2009) 'The game changer', Financial Times, 29 January 29: 10.

Standing, G. (2002) Beyond the new paternalism, London:Verso.

Standing, G. (2006) 'CIG, COAG and COG: a comment on a debate', in E. Olin Wright (ed) Redesigning distribution: Basic income and stakeholder grants as cornerstones for an egalitarian capitalism, London and New York, NY:Verso.

Standing, G. (2009) Work after globalization: Building occupational citizenship, Cheltenham: Edward Elgar.

Stephens, P. (2009) 'Averting a slump: it's the politics, stupid', Financial Times, 3 February: 9.

Stiglitz, J. (2009) 'Do not squander America’s stimulus on tax cuts', Financial Times, 16 January: 9.

The Economist (2008) 'The economy: days of open wallet', The Economist, 13 December: 54.

The Economist (2009a) 'Trapped: why the ECB is not cutting rates to zero', The Economist, 31 January: 74.

The Economist (2009b) 'The collapse of manufacturing', The Economist, 21 February: 11.

The Economist (2010) 'Picking winners, saving losers', The Economist, 7 August: 54. Warner,J. (2009) 'Depression and the protectionist threat', The Independent, 11 March. 
Wilkinson, R. and Pickett, K. (2009) The spirit level: Why more equal societies almost always do better, London: Allen Lane.

Woodley, T. (2009) Speech to the United Left launch meeting, Birmingham, 23 February, www.unitedleft.org/2009/02/tony-woodleys-speech-to-united-left. html

Guy Standing, Department of Social and Policy Sciences, University of Bath, UK, g.standing@bath.ac.uk 